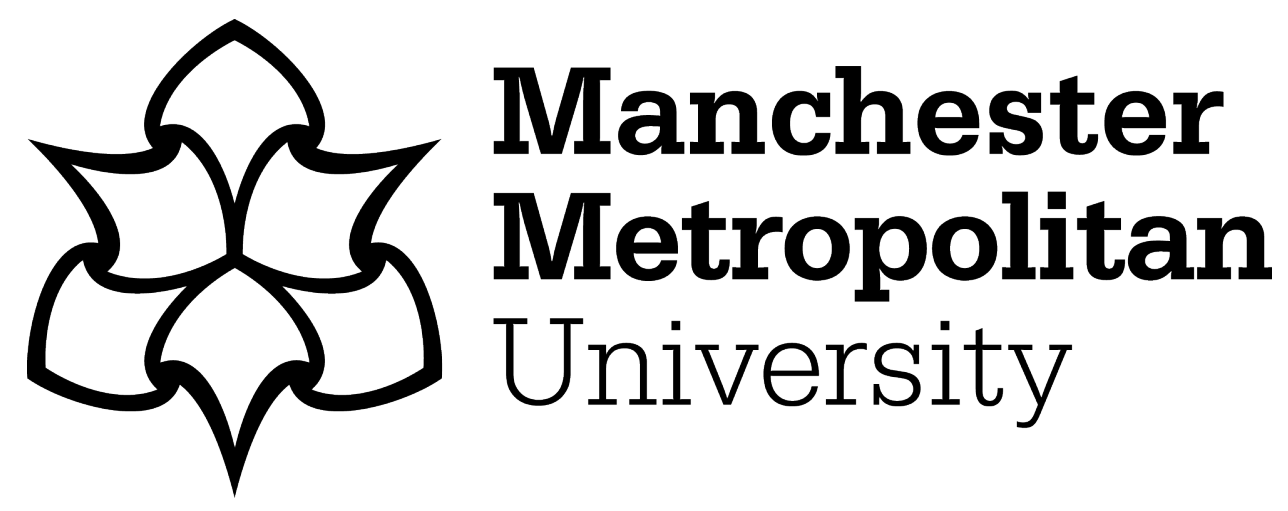

Rahmana, Osmud, Chen, Zhimin ORCID logoORCID: https://orcid.org/00000001-8086-4201, Fung, Benjamin CM and Kharbd, Devender (2020) CrossNational Study of Young Female Consumer Behaviour, Innovativeness and Apparel Evaluation: China and India. Journal of the Textile Institute, 111 (3). pp. 334-344. ISSN 0040-5000

Downloaded from: https://e-space.mmu.ac.uk/623103/

Version: Accepted Version

Publisher: Taylor \& Francis

DOI: https://doi.org/10.1080/00405000.2019.1632627

Please cite the published version 


\title{
A Cross-National Study of Young Female Consumer Behaviour, Innovativeness and Apparel Evaluation: China and India
}

\author{
Osmud Rahman ${ }^{\mathrm{a}}$, Zhimin Chen ${ }^{\mathrm{b}}$, Benjamin C.M. Fung ${ }^{\mathrm{c}}$ and Devender Kharb ${ }^{\mathrm{d}}$
}

${ }^{a}$ School of Fashion, Ryerson University, Toronto, Canada; ${ }^{b}$ Manchester Fashion Institute, Manchester Metropolitan University, Manchester, United Kingdom; 'School of Information

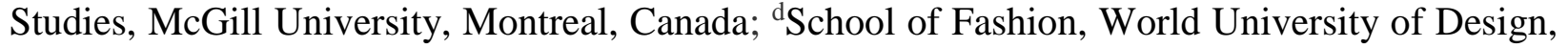
New Delhi, India

\begin{abstract}
In order to advance our knowledge about consumers' shopping behaviour and preferences in two emerging markets (China and India), the current study was undertaken to investigate (1) apparel consumers' shopping behaviour; (2) the effect of consumer innovativeness, and (3) the salient impact of apparel evaluative cues. An online self-administered survey consisted of shopping behavioural questions, the Domain Specific Innovativeness (DSI) scale, twelve apparel cues, and demographic questions were used for this study. In total, 266 and 236 usable data were collected from Chinese and Indian female participants respectively. The findings indicated that Chinese and Indian fashion innovators tended to spend more money on new clothes than non-innovators. Chinese fashion innovators spent significantly more time shopping online than did Indian innovators. In terms of the importance of evaluative cues, fashion innovators and non-innovators in both countries considered fit to be the most important cue; style, colour, and comfort played a relatively important role in clothing evaluation as well, but ease of care and durability were cited as relatively less important among many other cues. The two least important cues were brand name and country of origin.
\end{abstract}

KEYWORDS: consumer behaviour, consumer innovtiveness, product evaluation, China, India, Domain Specific Innovativeness scale

\section{Introduction}

In 2016, China launched a new Five-Year Plan (2016-2021) for economic and social development with emphasis on new-style consumption to improve the quality of life, as well as to boost economic growth (HKTDC, 2016) Areas targeted for improvement/expansion included green, fashionable and quality consumption. Even with the economic slowdown since 2012, China's economy grew at an annual rate of $6.9 \%$ in the first and second quarters of 2017, compared to $6.7 \%$ a year earlier (Gray, 2017; Wildau \& Mitchell, 2017). According to the prediction of PricewaterhouseCoopers (PwC, 2017), China will become the largest economy in the world, followed by India and the United States by 2050. India is another emerging country in the AsiaPacific region, and has experienced rapid economic growth since the launch of its New Economic Policy in 1991 (Deloitte, 2013). In 2016, India's annual GDP growth rate was 7\% (ENS Economic Bureau, 2017; Gray, 2017) - which means that it has overtaken China as one of the fastest-growing economies in the world (Khan, 2016). China's total retail sales are expected to reach $\$ 4.99$ trillion (Reuters, 2016), with India's being \$1.3 trillion by 2020 (The Times of India, 2015). Another recent study (Yu et al., 2015) reported that consumers' expenditure on apparel and footwear in Asia is expected to grow from US\$625 billion in 2014 to US $\$ 920$ billion by 2018 . Due to this rapid economic growth, China and India play a very important role in future global fashion consumption. In order to gain a deeper understanding of consumer innovativeness between these two emerging markets, the following questions were raised to guide and direct this research study: 
How may consumer innovativeness differ across nations? Are there any differences in consumer behaviour between different consumer groups (innovators and non-innovators, Chinese and Indian)? What type of product attributes would be preferred by the innovators and non-innovators? Does fashion innovativeness affect consumer shopping behaviours and clothing choices differently in China and India?

In order to develop appropriate products and effective marketing strategies for these two major and fast-changing markets, it is imperative for multinational companies to understand the changes in consumers' needs and aspirations. Previous studies (Narang 2010; Phau \& Lo, 2004) have found that demographic information cannot fully explain the consumers' buying motives and preferences in different socio-cultural contexts. In this study, we proposed that shopping behaviour (online and offline), consumer innovativeness (fashion innovators and non-innovators), and clothing evaluative cues (extrinsic and intrinsic) could greatly affect consumer choices and purchasing decisions of new fashion products. Although a considerable amount of literature has focused on shopping behaviour (Rahman, Wong \& Yu, 2016; Roy, Sethuraman \& Saran, 2016), consumer innovativeness (Im, Bayus \& Mason, 2003; Jordaan \& Simpson, 2006; Phau \& Lo, 2004), and clothing choice (Forsythe, Kim \& Peter, 1999; Rahman, Fung, Chen \& Gao, 2018), little is known about the relationship and significance of these three dimensions in China and India. As shown in Table 1, most cross-national studies on innovativeness were conducted predominantly in the United States and Europe, and many were not focused on apparel products. Due to the lack of literature on this particular topic, the present study seeks to advance our knowledge regarding consumer shopping behaviours and preferences in a Chinese/Indian cross-national context. In order to understand the similarities and differences between the consumers of these countries, the current study was undertaken to investigate (1) consumer apparel shopping behaviours; (2) the effect of consumer innovativeness, and (3) the salient impact of apparel evaluative cues.

\begin{tabular}{|c|c|c|c|c|}
\hline $\begin{array}{l}\text { Author(s)/ } \\
\text { Year }\end{array}$ & Country \& Sample & $\begin{array}{l}\text { Domain of } \\
\text { Interest }\end{array}$ & $\begin{array}{l}\text { Approach / } \\
\text { Measuring Method }\end{array}$ & Focus of Study \\
\hline $\begin{array}{l}\text { Goldsmith et } \\
\text { al. (1998) }\end{array}$ & $\begin{array}{l}\text { U.S.A.: } \mathrm{N}=121 \\
\text { German: } \mathrm{N}=113 \\
\text { France: } \mathrm{N}=175\end{array}$ & Wine & $\begin{array}{l}\text { Domain Specific } \\
\text { Innovativeness (DSI) } \\
\text { Scale (Goldsmith \& } \\
\text { Hofacker, 1991) }\end{array}$ & $\begin{array}{l}\text { A transnational evaluation of } \\
\text { the psychometric soundness of } \\
\text { the DSI. }\end{array}$ \\
\hline $\begin{array}{l}\text { Blake et al. } \\
(2007)\end{array}$ & $\begin{array}{l}\text { Austria: } \mathrm{N}=106 \\
\text { Canada: } \mathrm{N}=60 \\
\text { Iran: } \mathrm{N}=123 \\
\text { Taiwan: } \mathrm{N}=128 \\
\text { U.S.A.: } \mathrm{N}=208\end{array}$ & $\begin{array}{l}\text { Online } \\
\text { shopping: } 11 \\
\text { services \& } \\
\text { products }\end{array}$ & $\begin{array}{l}\text { Domain Specific } \\
\text { Innovativeness (DSI) } \\
\text { Scale (Goldsmith \& } \\
\text { Hofacker, 1991) }\end{array}$ & $\begin{array}{l}\text { The adoption/use of online } \\
\text { shopping }\end{array}$ \\
\hline $\begin{array}{l}\text { Quigley \& } \\
\text { Notarantonio } \\
(2009)\end{array}$ & $\begin{array}{l}\text { U.S.A.: } \mathrm{N}=189 \\
\text { Austria: } \mathrm{N}=173\end{array}$ & Fashion & $\begin{array}{l}\text { Domain Specific } \\
\text { Innovativeness (DSI) } \\
\text { Scale (Goldsmith \& } \\
\text { Hofacker, 1991) }\end{array}$ & $\begin{array}{l}\text { The purchase behaviour of } \\
\text { fashion leaders and fashion } \\
\text { followers among U.S. and } \\
\text { Austrian fashion consumers. }\end{array}$ \\
\hline $\begin{array}{l}\text { Bartels \& } \\
\text { Reinders } \\
(2010)\end{array}$ & $\begin{array}{l}\text { U.S.A.: } N=1001 \\
\text { U.K.: } N=1010 \\
\text { Germany: } N=961\end{array}$ & $\begin{array}{l}\text { Organic } \\
\text { food }\end{array}$ & $\begin{array}{l}\text { Domain Specific } \\
\text { Innovativeness (DSI) } \\
\text { Scale (Goldsmith \& } \\
\text { Hofacker, 1991); }\end{array}$ & $\begin{array}{l}\text { Compares the effects of } \\
\text { domain-specific innovativeness, } \\
\text { social representation of new } \\
\text { foods, and social identification } \\
\text { in the context of the acceptance } \\
\text { of new food products. }\end{array}$ \\
\hline
\end{tabular}




\begin{tabular}{|c|c|c|c|c|}
\hline $\begin{array}{l}\text { Lim \& Park } \\
\text { (2013) }\end{array}$ & $\begin{array}{l}\text { U.S.A.: N=349 } \\
\text { South Korea: } \\
N=350\end{array}$ & $\begin{array}{l}\text { Electronic } \\
\text { products }\end{array}$ & $\begin{array}{l}\text { Innate innovativeness } \\
\text { (Goldsmith } \text { et al., } \\
\text { 1995); DSI Scale } \\
\text { (Goldsmith et al., } \\
\text { 1995) }\end{array}$ & $\begin{array}{l}\text { The effects of national culture } \\
\text { and individuals' } \\
\text { cosmopolitanism on consumer } \\
\text { innovativeness and innovation- } \\
\text { adoption behaviour. }\end{array}$ \\
\hline $\begin{array}{l}\text { Truong } \\
\text { (2013) }\end{array}$ & $\begin{array}{l}\text { U.K.: } N \approx 150 \\
\text { France: } N \approx 150 \\
\text { Germany: } N \approx 150\end{array}$ & $\begin{array}{l}\text { Video-on- } \\
\text { demand } \\
\text { (VOD) } \\
\text { service }\end{array}$ & $\begin{array}{l}\text { Domain Specific } \\
\text { Innovativeness (DSI) } \\
\text { Scale (Goldsmith \& } \\
\text { Hofacker, 1991) } \\
\end{array}$ & $\begin{array}{l}\text { The effects of consumer } \\
\text { innovativeness on attitude } \\
\text { toward a service-based } \\
\text { innovation across cultures }\end{array}$ \\
\hline
\end{tabular}

Table 1. Cross-national studies of consumer innovativeness

\section{Literature review and hypotheses development}

\section{Consumer innovativeness and measuring methods}

Im, Kim and Peter (2003: 62) conceptualized consumer innovativeness as "the predisposition to buy new and different brands and products rather than remain with previous choices and consumption patterns". Some prior research has suggested that consumer innovativeness greatly affects consumer adoption of new products (Chao, Reid \& Mavondo, 2012; Im, Kim \& Peter, 2007; Roehrich, 2004). In fashion, innovators are those individuals who have the tendency to adopt new brands, fashionable products and ideas at an earlier stage than other consumers. Kang and Park-Poaps (2010) found that fashion innovativeness was positively associated with hedonic and adventure-shopping motivations. Although different approaches and measuring methods (e.g., time of adoption and cross-sectional) were developed in the past, there is no consensus among researchers about the effectiveness of different measuring techniques (Hauser, Tellis \& Griffin, 2006). According to some researchers (Bigné-Alcañiz, Ruiz-Mafé, Aldás-Manzano \& Sanz-Blas, 2008), general/global innovativeness and domain-specific innovativeness (DSI) were the two central approaches.

\section{General/Global Innovativeness and Domain-Specific Innovativeness (DSI)}

Global innovativeness is linked to personal traits that include intellectual, perceptual and attitudinal characteristics (Joseph \& Vyas, 1984), which can also be defined as a "willingness to try new things" (Goldsmith, 1990-1991). As Venkatraman (1991) suggests, global innovativeness is the personality trait that innately predisposes individuals to adopt new ideas, products and services earlier than others in a social system. Domain-specific innovativeness can be defined as traits directed toward a specific product domain (Hirunyawipada \& Paswan, 2006). Several research studies (Goldsmith, 1990-1991; Goldsmith \& Newell, 1997; Muzinch, Pecotich \& Putrevu, 2003) have pointed out that consumers who are innovators or early-adopters of one specific new product (e.g., clothing) may not necessarily adopt other types of new products (e.g., wine) at the introductory stage. Thus, it is not accurate to generalize innovative behaviour across all product categories. Although researchers have employed different techniques and approaches to measure innovativeness, some studies (Goldsmith \& Flynn, 1995; Goldsmith \& Hofacker, 1991) found that domain-specific measures are more predictive for the adoption of new products than global innovativeness. Another study conducted by Citrin, Sprott and Silverman (2000) also confirmed that domain-specific innovativeness (DSI) is a more reliable and accurate predictor of consumer-adoption behaviour as compared to the global innovativeness. A number of empirical studies conducted in different countries such as the USA, France and Germany also indicated that 
DSI was the most useful scale for measuring innovativeness in a specific product domain (Chakrabarti \& Baisya, 2009; Handa \& Gupta, 2009; Hynes \& Lo, 2006; Klink \& Athhaide, 2010). Due to the reliability of the DSI scale and the fact that fashion is the specific domain of interest, this measuring instrument was adopted for the present study.

\section{Shopping behaviours of fashion innovators and non-innovators}

Fashion innovativeness does not merely reflect a consumers' buying behaviours, but also their desire and tendency and to learn about a new fashionable product. In many cases, fashion innovators spend a great deal of time seeking product novelty, innovativeness and uniqueness to satisfy their experiential and emotional needs including fantasy, arousal, excitement, selfgratification, enjoyment, pleasure and/or curiosity. According to several previous apparel studies (Goldsmith \& Stith 1993; Phau \& Lo, 2004), innovators are more interested in new fashion trends and clothing styles than non-innovators. In a similar vein, a study conducted in Turkey (Uray \& Dedeoglu, 1997) also reported that innovators spent more time and money on new clothing products than did non-innovators. Another prior research conducted in various countries (Blake, Valdiserri, Neuendorf \& Valdiserri, 2007; Phau \& Lo, 2004; Quigley \& Notarantonio, 2009; Roehrich, 2004) has indicated that consumers who scored high in innovativeness tended to shop more frequently and spend more money on new fashionable products than average consumers. With such perspective, it is reasonable to suggest that fashion innovators may behave similarly regardless to their country of residence (China or India in our case) and method of shopping (offline or online). Based on the previous empirical findings, the following hypothesis was developed:

H1: Fashion innovators spend more time shopping online (e-retail) and offline (brick-andmortar stores) for new apparel products than do fashion non-innovators in both countries - China and India

Fashion innovators are more fashion conscious and place greater concern on social values than the non-innovator (Quigley \& Notarantonio, 2009); therefore, they are willing to spend more money on symbolic goods such as new apparel to build their identity and social status. On the contrary, non-innovators are more price conscious when they shop for clothing (Goldsmith \& Newell, 1997), and due to their price sensitivity, they are more likely to shop at discount stores than at high-end venues (Lumpkin \& McConkey, 1984). Another recent study (Rahman \& Kharb, 2018) also offers similar empirical support, their findings indicated that fashion innovators spent more money on new clothes than non-innovators. Based on the previous research findings, the following hypothesis was proposed:

H2: Fashion innovators spend more money on new apparel products than do fashion noninnovators in both countries - China and India

Apparel shopping is one the prevailing leisure activities for many Chinese and Indian consumers, particularly among the young. For example, a study (Zhang, 2005) conducted in China reported that adolescent consumers spent about $13.3 \%$ of their leisure time at fashion stores, versus 8.3\% at fast-food restaurants. Some recent studies (e.g., Cotton Incorporated, 2016; Zipser, Chen 
\& Gong, 2016) also revealed that young Chinese and Indian consumers are fashion conscious and highly receptive to new clothing styles, and many of them enjoy apparel shopping. Another recent study (Rahman \& Kharb, 2018) found that young Indian consumers spent more time at brick-andmortar stores to shop for new clothes than on the internet. They shop at retail stores for a number of reasons, which can include to escape from daily routine, seek product information, spend time with friends and family, and/or to browse the stores for fun (Kaur \& Singh, 2007; Rahman, Wong \& Yu, 2016).

Although e-commerce is growing in both China and India, it seems that many consumers still prefer shopping at the brick-and-mortar stores for the aforementioned reasons (Zipser, Chen \& Gong, 2016). On the basis of previous research, the following hypothesis was formulated:

H3: Chinese and Indian consumers (fashion innovators and non-innovators) prefer shopping for new apparel products at brick-and-mortar stores more than online shopping.

In terms of e-retailing, the Asian-Pacific region was the world market's fastest growing region in 2015, accounting for more than half of global online retail sales in that year (Deloitte, 2017). According to the National Bureau of Statistics (2017), China's online retail sales increased 31.9\% year-on-year to RMB858 (US\$129) billion in January - February 2017. Another study conducted by Cotton Incorporated (2016) reported that $96 \%$ of their Chinese respondents preferred shopping for apparel online. PricewaterhouseCoopers stated in an e-commerce report (PwC, 2017; p. 3) that "China is the largest and most innovative retail e-commerce market in the world." In comparison to China, the number of Indian internet users is very low due to "poor infrastructure, low internet penetration and difficulties with basic enablers like online payments" (Yu et al., 2015). In addition, many Indian consumers are highly quality conscious and prefer not to purchase products online (Khare, 2016). Many wish to have direct physical contact with apparel products (include touching, interacting, and trying on the clothing articles) prior to their purchases. With this perspective, the following hypothesis was developed:

H4: Chinese consumers (innovators and non-innovators) shop more frequently online for new apparel products than Indian consumers (innovators and non-innovators)

\section{Clothing evaluative cues}

Based on the cue utilization theory (Olson and Jacoby, 1972), consumers often use different product cues concurrently when evaluating, comparing and selecting products. Product attributes have been dichotomized into extrinsic and intrinsic categories (Hines and Swinker 2001). Extrinsic cues are product-related attributes such as brand name, price and country of origin, as they are not directly attached to the product. On the contrary, intrinsic cues involve a product's concrete characteristics and physical properties such as fabric, colour, style, fit, comfort and durability. In addition to these two categories, several research studies (e.g., Rahman, Wong \& Yu, 2017; Swan and Combs, 1976) suggested that intrinsic cues can be further divided into psychic and physical utilities. Psychic utility refers to a product's aesthetic characteristics: style, fabric and colour. Physical utility is referred to product performance: fit, durability, comfort, and ease of care. Although there is no consensus as to what product cues should be used for apparel research, the most frequently chosen cues have been price, brand name, country of origin, style, fit, fabric, colour, quality/workmanship, wardrobe coordination, comfort, durability and ease of care (Hsu \& Burns, 2002; Rahman, 2011). It is also important to note that consumer preferences for product cues may not be the same between consumer groups (fashion innovators vs. fashion non- 
innovators), product types (publicly consumed products vs. privately consumed products), and nations (China vs. India).

\section{Fashion innovators and non-innovators}

Fashion clothing is closely related to the individual self. Consumers often use clothing to express themselves, elevate social status, (re)construct identity, and/or create symbolic meanings in different socio-cultural contexts (Rahman, Liu \& Cheung, 2012). However, the symbolic meanings associated with clothing may vary considerably among consumers and across nations (Rahman, Yan \& Liu, 2010) depending on personal tastes, needs, fashion consciousness, and socio-cultural values. For example, fashion innovators usually pay more attention to visual cues such as style and colour in order to create a new and fashionable look in the public eye (Beaudoin. Moore \& Goldsmith, 2000; Law, Zhang \& Leung, 2000). On the contrary, fashion non-innovators are those who are less concerned with the latest trends and fashionable styles; for this consumer group often adopts a new product after it has been widely accepted by others. In other words, fashion innovators are more concerned with the aesthetics of a product for higher mental stimulation than their counterpart non-innovators. According to several previous fashion studies (Gitimu, Work \& Robinson, 2013; O'Cass, 2001), innovators were more interested in fashion, and tended to use more product cues to evaluate clothing items than the non-innovators. Workman and Studak (2006) also found that fashion change agents had a want-based approach (hedonic motivation), whereas non-innovators approached fashion from a need-based perspective (utilitarian motivation). Hedonic motivations are more related to the aesthetic, experiential and emotional benefits, while utilitarian motivations are related to the instrumental and functional properties of a product. Based on the empirical findings of prior literature, the following hypotheses were therefore developed:

H5a: Fashion innovators rely more significantly on psychic cues (style, colour and fabric) to evaluate new apparel products than do the non-innovators in China

H5b: Fashion innovators rely more significantly on psychic cues (style, colour and fabric) to evaluate new apparel products than do the non-innovators in India

H6a: Fashion non-innovators rely more significantly on physical cues (comfort, durability, ease of care) to evaluate new apparel products than do fashion innovators in China

H6b: Fashion non-innovators rely more significantly on physical cues (comfort, durability, ease of care) to evaluate new apparel products than do fashion innovators in India

Brand names can be used to convey personality, construct or enhance an individual's self, elevate social status, and/or reduce buyer effort and risk. According to the results of previous studies (Beaudoin, Moore \& Goldsmith, 2000; Kang \& Park-Poaps, 2010; Koksal, 2014), consumer innovativeness was positively related to brand sensitivity and shopping motivation. In other words, consumers who are actively engaged in fashion are more likely to use brand names of apparel products to evaluate and justify their purchases. In a similar vein, another study (Holstius \& Paltschik, 1983) reported that brand name could greatly affect the perceived quality of clothing among fashion-minded consumers, but not among the less concerned general consumers. With such a perspective, the following hypotheses were developed: 
H7a: Fashion innovators rely more significantly on brand name to evaluate new apparel products than do non-innovators in China

H7b: Fashion innovators rely more significantly on brand name to evaluate new apparel products than do non-innovators in India

The results of a survey conducted by Nielsen (2013) in 58 countries indicated that Chinese consumers spent more money on branded products than all other countries, followed by India and then Vietnam. In general, the new generation of sibling-less Chinese young adults are highly aware of global fashion trends, and are brand savvy and luxury conscious (Debnam \& Svinos, 2007; Rahman, Wong \& Yu, 2016). It is reasonable to suggest that Chinese consumers have relatively more knowledge and shopping experience with international brands than do their Indian counterparts. According to Medh (2012), India is at least 10 to 15 years behind China in this respect. Many multinational firms and retailers had never set foot in India until the 1990s - partly due to cultural differences, market regulations, and infrastructural challenges in this country. Past studies (Forsythe, Kim \& Peter, 1999) revealed that if consumers had limited experience with a product, they tended to rely more heavily on brand name to evaluate and justify their purchases. Based on this discussion, the following hypothesis was developed:

H8: Indian fashion innovators rely more significantly on brand name to evaluate new apparel products than do Chinese innovators

Lascu and Babb (1995) found that Polish consumers were less concerned with country-of-origin attribute, especially if it is a basic, inexpensive and widely accepted commodity. According to many apparel studies conducted in different countries including Canada, China, Japan and the United States (Kawabata \& Rabolt, 1999; Rahman, Zhu \& Liu, 2008; Rahman, Yan \& Liu, 2009), country of origin was often perceived as the least or the second-least important cue among many other apparel attributes. In other words, many consumers do not view country of origin as one of the important evaluative cues when they shop for clothing. Therefore, the following research question was proposed:

H9: Chinese and Indian fashion innovators rely less significantly on country of origin to evaluate new apparel products than other product cues

Consumers' perception on price often varies across nations due to many factors, including cost sensitivity and value consciousness. For example, a cross-national study conducted by Dunn (1996) found that price was considered an important evaluative cue of apparel products by American women, but not by their Mexican counterparts. According to the International Monetary Fund World Economic Outlook (IMF, 2015), the GDP per capita of China in that year was $\$ 7,589$ per person, while it was $\$ 1,627$ in India (based on the nominal terms). So it is reasonable to believe that Chinese consumers have more disposable income, and are less price-conscious, than Indian consumers. Prior research (e.g., Chao \& Schor, 1998) has indicated that income is positively associated with status-seeking and purchasing/ownership of material goods. Such a perspective would suggest that the price evaluative cue could play a relatively more significant role to the consumers in India than in China, hence the following hypothesis was developed: 
H10: Indian fashion innovators rely more significantly on price to evaluate new apparel products than do Chinese innovators

\section{Methodology}

\section{Development of online survey}

An online self-administered questionnaire consisting of shopping behavioural questions, the DSI measuring scale, twelve apparel cues, and demographic questions were used for this study. For example, the behavioural questions include "How many times do you shop for new clothes online each year?", "How many times do you shop for new clothes at the brick-and-mortar stores each year?", and "How much money do you usually spend on new clothes per single shopping trip?"

To measure consumer innovativeness, Goldsmith and Hofacker's (1991) Domain Specific Innovativeness (DSI) Scale was adopted. DSI can be applied to a wide array of product/service domains, including apparel products. Numerous studies have demonstrated that the DSI Scale is reliable (between 0.81 and 0.86), valid and internally consistent (Bearden, Netemeyer \& Mobley, 1993). This is a psychometrically-sound instrument consists of six statements, with three positively worded and three negatively worded. In addition to the DSI scale, twelve product cues were adopted from previous apparel studies (Rahman, 2011; Rahman, Yan \& Liu, 2009) to measure and identify the most frequently used cues for fashion evaluation. The selection of these product cues was determined by four judges (two fashion practitioners and two fashion professors) to ensure cross-national appropriateness and relevancy. This validation process among the judges was important to improve the effectiveness of our instrument. A five-point Likert-type response scale ( 5 = strongly agree/very important, 1 = strongly disagree/unimportant) was used for measuring fashion innovativeness and the salient effects of apparel cues.

The survey was originally developed in English for Indian participants, hence the backtranslation method was used to prepare the simplified Chinese version for use in mainland China (Brislin, 1986). Both the Chinese and English versions of the questionnaire were pretested with 15 Chinese and 15 Indian individuals to ensure clarity and accuracy, as well as to obtain feedback for any amendments. A commercial online data-gathering tool (Survey Monkey) was used for this study. There are several reasons why we chose online surveys over traditional pencil-and-paper surveys: to lower administrative time and financial costs, minimize coding time and errors, and provide more convenience for the participants (Kang \& Park-Poaps, 2010). However, the response rate of online survey is relatively low as compared to pencil-and-paper survey, the participants must be computer-literate and have an access to the internet, and the questions cannot fully capture participants' feelings and personal experiences. The survey data was primarily collected from convenience sampling through the assistance of acquaintances and friends in China and India. Individuals were approached through email and text message (e.g., WeChat in China). Although our questionnaire survey collected data from both genders, this paper solely focused on the responses of young females for two major reasons. First, female consumers are more involved in fashion consumption and sensitive to apparel cues as compared to male counterparts (Rahman, Fung, Chen \& Gao, 2017). Second, both Chinese and Indian samples are skewed toward young female consumers, therefore, males' responses were not included in this study.

\section{Analysis and results}

In total, 266 and 236 usable data were collected from Chinese and Indian female participants respectively. The participants of each sample were classified into two consumer groups (fashion 
innovators and fashion non-innovators) by splitting the distribution of innovative scores based on one standard deviation above the mean value described in the Goldsmith and Flynn's (1992) study. As a result, $13.5 \%$ of the Chinese sample and $17.8 \%$ of the Indian sample were classified as innovators, while the remaining 230 Chinese (86.5\%) and 193 Indian (82.2\%) participants were defined as non-innovators. The Chinese participants were aged between 18 and $32(\overline{\mathrm{x}}=$ 24.12 or 24 years old), whereas the Indian participants were between 18 and $26(\bar{x}=19.91$ or 20 years of age). The higher percentage of innovators in the Indian sample may be linked to age difference between the samples (the Indian group being of lower age), as Uray and Dedeoglu (1997) reported in their study that the mean age of fashion innovators was lower than that of fashion non-innovators. In terms of annual income, Chinese $(\mathrm{n}=182,68.4 \%)$ and Indian $(\mathrm{n}=92$, $38.9 \%$ ) participants earned $¥ 60,000 / \mathrm{US} \$ 8,944$ or less and Rs600,000/US\$8,649 or less respectively. It is important to note that Indian participants were relatively younger than their Chinese counterparts by about four years, and many of them had no income. According to studies (Khare \& Rakesh, 2010; Puddick \& Menon, 2012; Rahman \& Kharb, 2018) conducted in India, co-shopping with parents is very common, and "many young consumers depend on their parents to pay" for the apparel products that they want to purchase. (Rahman and Kharb, 2019; p.9)"

\section{Apparel shopping behaviour between fashion innovators and non-innovators}

Although the frequency that fashion innovators shopped annually for new clothes at brick-andmortar stores and online was slightly higher than for non-innovators in both countries; the $t$-test result does not show any significant differences between these two groups. In terms of the time spent at brick-and-mortar stores and online websites, there are no significant differences between fashion innovator and non-innovator groups in both China and India (see Table 2). Thus, H1 was not supported.

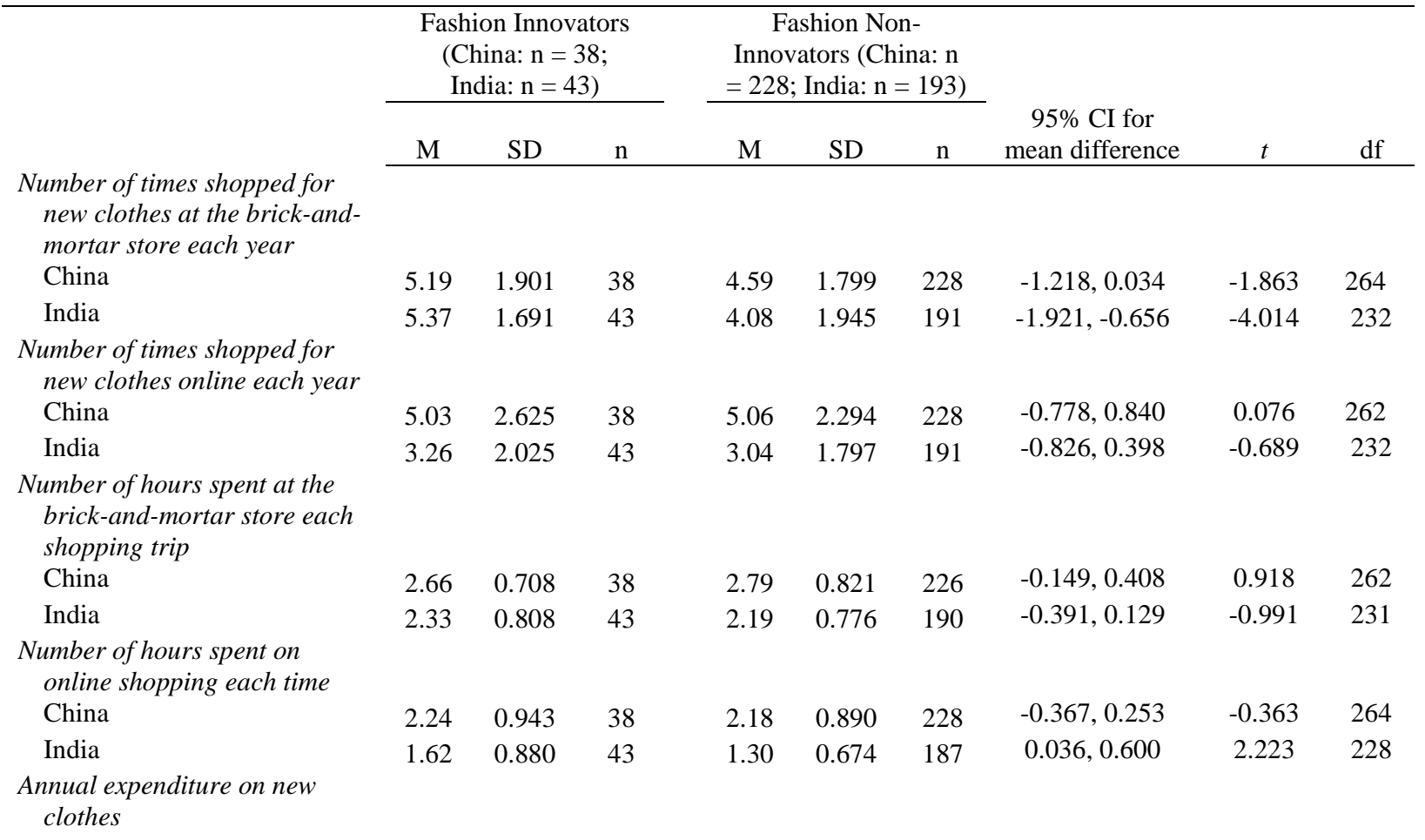




\begin{tabular}{cccccccccc} 
China & 3.27 & 1.521 & 37 & 2.49 & 1.285 & 228 & $-1.240,-0.318$ & $-3.330 *$ & 263 \\
India & 3.40 & 0.885 & 43 & 2.81 & 1.071 & 191 & $-0.942,-0.243$ & $-3.340 *$ & 232 \\
\hline$* p<0.05$ & & & & &
\end{tabular}

Table 2. $t$-test results of the frequency of apparel shopping and annual expenditure on new clothes of fashion innovators and non-innovators by country

As shown in Table 3, almost half of the Chinese fashion innovators (47.4\%) spent $¥ 13,000$ $(\approx \mathrm{US} \$ 1,966)$ or more on new clothes annually, compared to only $20.6 \%$ of the non-innovators. The Indian sample also revealed that fashion innovators tended to spend more money on new clothes than non-innovators (see Table 3). In addition, the $t$-test analysis in the present study suggests that there are significant differences between the mean scores for fashion innovators and non-innovators on annual apparel spending in both countries, so $\mathrm{H} 2$ was supported.

\begin{tabular}{lcccc}
\hline & Fashion Innovators & \multicolumn{2}{c}{ Fashion } \\
& & & \multicolumn{2}{c}{ Non-Innovators } \\
\cline { 2 - 5 } China $(N=266)$ & $\mathrm{n}$ & $\%$ & $\mathrm{n}$ & $\%$ \\
Less than $¥ 5,000(\approx \mathrm{US} \$ 756)$ & 6 & 15.8 & 60 & 26.3 \\
$¥ 5,000(\approx \mathrm{US} \$ 756)-¥ 8,999(\approx \mathrm{US} \$ 1,361)$ & 8 & 21.1 & 69 & 30.3 \\
$¥ 9,000(\approx \mathrm{US} \$ 1,361)-¥ 12,999(\approx \mathrm{US} \$ 1,966)$ & 5 & 13.2 & 52 & 22.8 \\
$¥ 13,000(\approx \mathrm{US} \$ 1,966)-¥ 16,999(\approx \mathrm{US} \$ 2,570)$ & 6 & 15.8 & 21 & 9.2 \\
$¥ 17,000(\approx \mathrm{US} \$ 2,570)$ or above & 12 & 31.6 & 26 & 11.4 \\
Missing & 1 & 2.6 & 0 & 0.0 \\
India $(N=236)$ & & & & \\
Less than Rs10,000 $(\approx \mathrm{US} \$ 157)$ & 2 & 4.7 & 27 & 14.0 \\
Rs10,000 $(\approx \mathrm{US} \$ 157)-\mathrm{Rs} 19,999(\approx \mathrm{US} \$ 315)$ & 5 & 11.6 & 50 & 25.9 \\
Rs20,000 $(\approx \mathrm{US} \$ 315)-\mathrm{Rs} 29,999(\approx \mathrm{US} \$ 473)$ & 9 & 20.9 & 47 & 24.4 \\
Rs30,000 $(\approx \mathrm{US} \$ 473)$ or above & 27 & 62.8 & 67 & 34.7 \\
Less than Rs10,000 $(\approx \mathrm{US} \$ 157)$ & 2 & 4.7 & 27 & 14.0 \\
\hline
\end{tabular}

Table 3. Chinese and Indian samples: The differences between fashion innovators and non-innovators on annual apparel expenditure

\section{Apparel shopping behaviour between Chinese and Indian fashion innovators}

On average, both Chinese $(\overline{\mathrm{x}}=5.18)$ and Indian $(\overline{\mathrm{x}}=5.37)$ fashion innovators shopped for new clothes on 10-12 occasions at brick-and-mortar stores per year. There were no statistically mean differences in shopping frequency and time spent at the brick-and-mortar stores between Chinese and Indian fashion innovators, as indicated in Table 4. In terms of online shopping behaviours, Chinese fashion innovators shopped for new clothes online 10-12 times $(\overline{\mathrm{x}}=5.03)$ per year, and and each time for about 3-4 hours $(\overline{\mathrm{x}}=2.24)$. Their Indian counterparts shopped on the internet 46 times $(\overline{\mathrm{x}}=3.26)$ per year and spent approximately $2-3$ hour $(\overline{\mathrm{x}}=1.30)$ each time. In addition, the $t$-test result indicated that there were statistically significant mean differences in online apparel shopping frequency $(t=3.420, \mathrm{df}=79, p=0.001)$ and time spent $(t=5.177, \mathrm{df}=79, p=0.000)$ between the Chinese and Indian fashion innovators. Based on these findings, both $\mathrm{H} 3$ and $\mathrm{H} 4$ were supported.

\begin{tabular}{lcc}
\hline Shopping Behaviour & $\begin{array}{c}\text { Chinese Innovators } \\
(\mathrm{n}=38)\end{array}$ & Indian Innovators \\
& $(\mathrm{n}=43)$
\end{tabular}




\begin{tabular}{|c|c|c|c|c|c|c|c|c|c|}
\hline & & & & & \multirow[b]{2}{*}{$\begin{array}{c}95 \% \mathrm{CI} \text { for } \\
\text { mean difference }\end{array}$} & \multirow[b]{2}{*}{$t$} & \multirow[b]{2}{*}{$\mathrm{df}$} \\
\hline & $\mathrm{M}$ & SD & $\mathrm{n}$ & $\mathrm{M}$ & SD & $\mathrm{n}$ & & & \\
\hline $\begin{array}{l}\text { Number of times shopped for } \\
\text { new clothes at the brick-and- } \\
\text { mortar store each year }\end{array}$ & 5.18 & 1.901 & 38 & 5.37 & 1.691 & 43 & $-0.982,0.606$ & -0.471 & 79 \\
\hline $\begin{array}{l}\text { Number of times shopped for } \\
\text { new clothes online each year }\end{array}$ & 5.03 & 2.625 & 38 & 3.26 & 2.025 & 43 & $0.740,2.801$ & $3.420 *$ & 79 \\
\hline $\begin{array}{l}\text { Number of hours spent at the } \\
\text { brick-and-mortar store each } \\
\text { shopping trip }\end{array}$ & 2.66 & 0.708 & 38 & 2.33 & 0.808 & 43 & -0.006 .0 .670 & -1.956 & 79 \\
\hline $\begin{array}{l}\text { Number of hours spent on } \\
\text { online shopping each time }\end{array}$ & 2.24 & 0.943 & 38 & 1.30 & 0.674 & 43 & $0.575,1.294$ & $5.177 *$ & 79 \\
\hline
\end{tabular}

Table 4. $t$-test results of the frequency of apparel online and offline shopping between Chinese fashion innovators and Indian fashion innovators

\section{The significant differences of apparel evaluative cues between fashion innovators and non- innovators in two emerging countries}

In order to ensure the quality of the measurement, Cronbach alpha coefficients were used to examine the reliability of each item, and according to Nunnally (1994), reliability coefficients of 0.70 or greater are considered to be "good"; while a minimum $\alpha$-value of 0.60 is "acceptable". Applied to the results from the current study, the multiple item scale of product cues was considered "very good" for the Indian sample (Cronbach's alpha scores from 0.784 to 0.802), and "satisfactory" for the Chinese sample (Cronbach $\alpha$ ranged from 0.678 to 0.74 ).

Interestingly, the most important cue for evaluating new clothes for all the participants was "perceived fit", regardless of their innovativeness and country of residence. Also, as shown in Table 5, the $t$-test analysis reveals that there were no significant differences in all the apparel cues between innovator and non-innovator groups in China and India, except for brand name and style in India only. In terms of the psychic cues (style, colour and fabric), only the Indian fashion innovators relied more significantly on style $(t=-2.343$, df $=230, p=0.020)$ than did the noninnovators. Based on these findings, H5a was not supported and H5b was partially supported. In addition, the findings indicate that non-innovators did not rely more significantly on the physical cues (comfort, durability, ease of care) to evaluate new clothing products than did innovators in either country, therefore, H6a and H6b were not supported.

Although there were statistically-significant mean differences in brand-name effects between fashion innovators and non-innovators in both Chinese $(t=-2.615, \mathrm{df}=264, p=0.009)$ and Indian $(t=2.140, \mathrm{df}=228, p=0.033)$ samples, the brand-name effects were not the same. Chinese fashion innovators relied more significantly on brand name to evaluate new clothing products than did non-innovators in that country. However, the result for the Indian sample was the opposite fashion non-innovators relied more significantly on brand name than did their counterparts and thus, H7a was supported but not H7b.

\begin{tabular}{|c|c|c|c|c|c|c|c|c|c|}
\hline \multirow[b]{3}{*}{ Apparel Cues } & \multicolumn{9}{|c|}{ China } \\
\hline & \multicolumn{3}{|c|}{$\begin{array}{l}\text { Fashion Innovators } \\
\qquad(\mathrm{n}=38)\end{array}$} & \multicolumn{3}{|c|}{$\begin{array}{c}\text { Fashion } \\
\text { Non-Innovators } \\
(\mathrm{n}=228)\end{array}$} & \multirow{2}{*}{$\begin{array}{l}95 \% \mathrm{CI} \text { for } \\
\text { mean } \\
\text { difference }\end{array}$} & \multirow[b]{2}{*}{$t$} & \multirow[b]{2}{*}{$\mathrm{df}$} \\
\hline & M & SD & $\mathrm{n}$ & M & SD & $\mathrm{n}$ & & & \\
\hline Quality - Workmanship & 4.61 & 0.595 & 38 & 4.55 & 0.678 & 228 & $-0.283,0.177$ & -0.450 & 264 \\
\hline Fit & 4.61 & 0.718 & 38 & 4.65 & 0.744 & 228 & $-0.130,0.207$ & 0.372 & 264 \\
\hline Style & 4.58 & 0.683 & 38 & 4.37 & 0.832 & 228 & $-0.491,0.070$ & -1.479 & 264 \\
\hline Colour & 4.45 & 0.828 & 38 & 4.43 & 0.818 & 228 & $-0.305,0.261$ & -0.153 & 264 \\
\hline Comfort & 4.42 & 0.758 & 38 & 4.54 & 0.710 & 228 & $-0.125,0.370$ & 0.977 & 264 \\
\hline
\end{tabular}

\begin{tabular}{|c|c|c|c|c|c|c|c|c|}
\hline \multicolumn{9}{|c|}{ India } \\
\hline \multirow{2}{*}{\multicolumn{3}{|c|}{$\begin{array}{l}\text { Fashion } \\
\text { Innovator } \\
(\mathrm{N}=43)\end{array}$}} & \multirow{2}{*}{\multicolumn{3}{|c|}{$\begin{array}{c}\text { Fashion } \\
\text { Non-Innovator } \\
(\mathrm{N}=193)\end{array}$}} & \multirow{3}{*}{$\begin{array}{l}95 \% \mathrm{CI} \text { for } \\
\text { mean } \\
\text { difference }\end{array}$} & & \multirow[b]{3}{*}{ df } \\
\hline & & & & & & & & \\
\hline M & SD & $\mathrm{n}$ & M & SD & $\mathrm{n}$ & & & \\
\hline 3.76 & 1.055 & 42 & 3.89 & 1.042 & 187 & $-0.220,0.482$ & 0.736 & 227 \\
\hline 4.84 & 0.433 & 43 & 4.73 & 0.647 & 192 & $-0.312,0.096$ & -1.043 & 233 \\
\hline 4.45 & 0.916 & 42 & 4.07 & 0.971 & 190 & $-0.707,-0.061$ & $-2.343^{*}$ & 230 \\
\hline 4.12 & 0.781 & 41 & 4.13 & 0.999 & 191 & $-0.318,0.336$ & 0.054 & 230 \\
\hline 4.52 & 0.740 & 42 & 4.47 & 0.886 & 188 & $-0.340,0.239$ & -0.343 & 228 \\
\hline
\end{tabular}




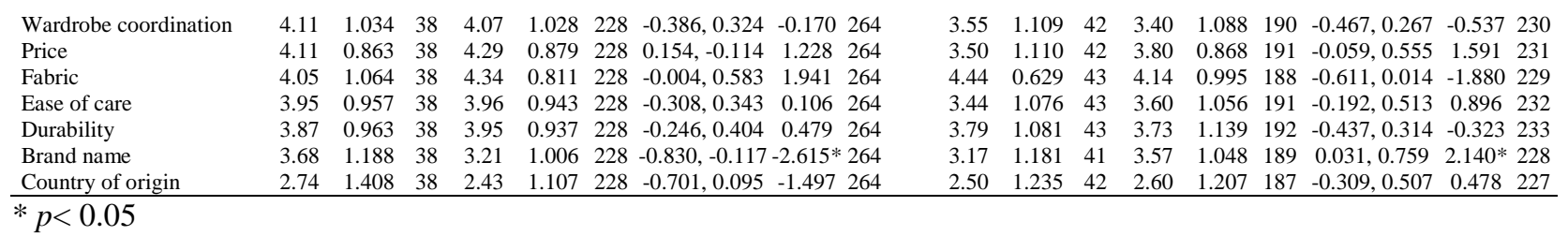

Table 5. Chinese and Indian samples: The differences between fashion innovators and fashion non-innovators on apparel evaluative cues

The significant differences in the influence of extrinsic cues between (1) Chinese fashion innovators and Indian innovators and (2) Chinese consumers and Indian consumers

As shown in Table 6, the result of the $t$-test scores reveal that there were no statistically significant mean differences in brand name being used as an important cue for clothing evaluation between Chinese and Indian fashion innovators. Therefore, H8: "Indian fashion innovators rely more significantly on brand name to evaluate new clothing products than the Chinese fashion innovators" was not supported. In terms of the country of origin, both Chinese $(\overline{\mathrm{x}}=2.74$, S.D. $=$ 1.408) and Indian fashion innovators $(\overline{\mathrm{x}}=2.50$, S.D. $=1.235)$ perceived this apparel cue as the least significant factor for clothing evaluation. It is evident that many consumers do not pay attention to the "country-of-origin" or "made in" label prior to making their purchases. This finding is consistent with several previous studies (Kawabata \& Rabolt, 1999; Rahman, 2011; Rahman, Zhu \& Liu, 2008). Therefore, it is reasonable to suggest that the level of awareness towards "country-of-origin" is low. According to the $t$-test analysis of country of origin, there was no significant difference between Chinese and Indian innovators. Thus, H9 was supported.

In regard to the price cue, a $t$-test analysis suggests that there were statistically significant mean differences in price $(t=2.491, \mathrm{df}=78, p=0.015)$ between China and India. Surprisingly, Chinese fashion innovators relied more heavily on the price cue to evaluate new apparel products than the Indian fashion innovators. Thus, H10 was not supported.

\begin{tabular}{|c|c|c|c|c|c|c|c|c|c|}
\hline \multirow[t]{2}{*}{ Apparel Product Cues } & \multicolumn{3}{|c|}{$\begin{array}{c}\text { Chinese Innovators } \\
(\mathrm{n}=38)\end{array}$} & \multicolumn{3}{|c|}{$\begin{array}{c}\text { Indian Innovators } \\
(\mathrm{n}=43)\end{array}$} & \multirow{2}{*}{$\begin{array}{l}95 \% \text { CI for } \\
\text { mean difference }\end{array}$} & \multirow[b]{2}{*}{$t$} & \multirow[b]{2}{*}{ df } \\
\hline & M & SD & $\mathrm{n}$ & $\mathrm{M}$ & SD & $\mathrm{n}$ & & & \\
\hline Quality - workmanship & 4.61 & 0.595 & 38 & 3.76 & 1.055 & 42 & $0.457,1.230$ & $4.342 *$ & 78 \\
\hline Fit & 4.61 & 0.718 & 38 & 4.84 & 0.433 & 43 & $-0.491,0.027$ & -1.784 & 79 \\
\hline Style & 4.58 & 0.683 & 38 & 4.45 & 0.916 & 42 & $-0.236,0.489$ & 0.695 & 78 \\
\hline Colour & 4.45 & 0.828 & 38 & 4.12 & 0.781 & 41 & $-0.035,0.687$ & 1.797 & 77 \\
\hline Comfort & 4.42 & 0.758 & 38 & 4.52 & 0.740 & 42 & $-0.437,0.231$ & -0.613 & 78 \\
\hline Price & 4.11 & 0.863 & 38 & 3.55 & 1.109 & 42 & $0.112,1.003$ & $2.491^{*}$ & 78 \\
\hline Wardrobe coordination & 4.11 & 1.034 & 38 & 3.50 & 1.110 & 42 & $0.126,1.084$ & $2.518 *$ & 78 \\
\hline Fabric & 4.05 & 1.064 & 38 & 4.44 & 0.629 & 43 & $-0.771,-0.008$ & $-2.032 *$ & 79 \\
\hline Ease of care & 3.95 & 0.957 & 38 & 3.44 & 1.076 & 43 & $0.053,0.958$ & $2.222 *$ & 79 \\
\hline Durability & 3.87 & 0.963 & 38 & 3.79 & 1.081 & 43 & $-0.378,0.533$ & 0.340 & 79 \\
\hline Brand name & 3.68 & 1.188 & 38 & 3.17 & 1.181 & 41 & $-0.018,1.045$ & 1.925 & 77 \\
\hline Country of original & 2.74 & 1.408 & 38 & 2.50 & 1.235 & 42 & $-0.351,0.825$ & 0.802 & 78 \\
\hline
\end{tabular}

$* p<0.05$

Table 6. The significant differences between Chinese sample and Indian sample on apparel product cues 


\section{Conclusion and implications}

Although fashion innovators spent more time shopping for clothing online and offline in both countries, there were no significant differences between innovator and non-innovator groups. These findings differ from earlier studies (Blake, Valdiserri, Neuendorf \& Valdiserri, 2007; Phau \& Lo, 2004; Quigley \& Notarantonio, 2009). In terms of expenditure on new clothes, there were significant differences between fashion innovators and non-innovators. Fashion innovators spent substantially more money on clothing than non-innovators in both countries. However, when comparing only fashion innovator shopping frequency between the two countries, it is evident that Chinese fashion innovators spent significantly more time shopping online than did Indian innovators. Although the former group shopped more frequently online than the latter group, the e-retailing business is expected to continue growing in both nations. E-commerce will be an important driver for the youth market, and particularly for the 'millennial' generation, who are regarded as 'digital natives'. However, India is facing a number of challenges arising from poor infrastructure, slower internet speed and connectivity, expensive broadband internet access, unreliable delivery mechanisms, and low penetration. In order to increase internet sales and penetration in India, the government, local communities, internet providers and fashion industry could all benefit from working together collectively to deal with these obstacles. In addition, fashion e-retailers and website designers may need to develop innovative strategies to speed up the product diffusion and adoption process.

In terms of the importance of evaluative cues, fashion innovators and non-innovators in both countries considered "fit" to be the most important cue; with style, colour, and comfort playing a relatively important role in clothing evaluation as well. Ease of care and durability were cited as relatively less important among these other cues. The two least important cues were brand name and country of origin. Overall, the findings are consistent across the consumer innovativeness groups of both countries, except in the case of fabric. Indian consumers, including both innovators and non-innovators, were relatively more concerned with fabric than their Chinese counterparts. In addressing the style cue, incorporating traditional/cultural elements in a modern/contemporary design could play an important part in the success or failure of a product in India (Rahman \& Kharb, forthcoming). In other words, hybrid designs could be an appropriate approach for this particular market. As Sandhu (2015) points out in her book entitled Indian Fashion: Tradition, Innovation, Style, "As the sari was becoming a less-viable option for the age group, the salwar karmeez was the perfect hybrid choice."

In addition, fashion innovators and non-innovators did not solely focus on either the psychic utilities (style, colour, fabric) or just the physical utilities (comfort, ease of care, durability) when they evaluate clothing. Many young Chinese and Indian consumers, for instance, do not make purchasing decisions based on a "monolithic" feature, but rather, on both psychic values (symbolic or sensory) and physical values (functional or utilitarian) with diverse benefits.

When consumers are knowledgeable and motivated enough to compare alternatives, they have a high tendency to use brand name as a heuristic basis for evaluation (alongside many other factors) to justify their purchasing decisions (Kwang et al., 2008). According to the results from the current study focusing on young consumers, brand name was not perceived as an important cue for clothing evaluation. Although urban youths in China and India are increasingly conscious of brands, many of them are still value seekers (Ackerman \& Tellis, 2001; Puddick \& Menon, 2012). Thus, it is reasonable to believe that young Chinese and Indian consumers are willing to trade up for those designer or branded goods that offer the most value and benefit. In other words, they do not purchase a product based only for its label, but also with other overall benefits in mind. As 
Puddick and Menon (2012; p. 51) asserted, "Value-conscious shopping is ingrained into Indian culture. Indians know the price of items in different markets and they will absolutely shop around for the best deal."

According to the present study, Chinese fashion innovators relied more heavily on price cues to evaluate new clothing products. This finding was unexpected because China's GDP per capita is higher than that of India, and it might have been reasonable to assume that Chinese consumers would have more disposable income to spend on clothing and be less-sensitive to price. Possible explanations could be: (1) Chinese young consumers have limited budgets to spend on clothing; (2) Chinese consumers are more cautious about each apparel expenditure event in order to maintain their ability to engage in more frequent purchases; (3) Indian parents often co-shop with their children and are the ones who physically pay for the purchases (Rahman \& Kharb, 2018), and (4) the age differences between the two samples.

\section{Limitations and future research}

The present study should enable multi-national fashion retailers to understand the benefits of identifying their potential customers as either fashion innovators or as non-innovators, and then to plan improved design strategies, marketing programs and company policies according to these specific needs. However, the study does have several limitations. Firstly, the current study was focused only on young female consumers; making our findings unlikely to represent the larger populations of China and India. Future studies might therefore utilize more diverse samples including different age groups and genders to obtain more generalized outcomes. Secondly, fashion clothing was selected for this study, hence its results may not be valid nor applicable to other consumer products for which further research would be recommended. Thirdly, future research may usefully be extended to investigate consumers' interactivity and engagement with online/offline shopping, and their cognitive and affective responses to e-retailing websites. Considerations to include cross-cultural examinations of global social networking, advertising and e-retailing strategies is also recommended.

\section{References}

Ackerman, D. \& Tellis, G. (2001). Can culture affect prices? A cross-cultural study of shopping and retail prices. Journal of Retailing, 77, 57-82.

Banerjee, S. (2008). Dimensions of Indian culture, core cultural values, marketing implications An analysis. Cross Cultural Management: An International Journal, 15, 367-378.

Bartels, J. \& Reinders, M.J. (2010). Social identification, social representations, and consumer innovativeness in an organic food context: A cross-national comparison. Food Quality and Preference, 21, 347-352.

Bearden, W.O., Netemeyer, R.G. \& Mobley, M.F. (1993). Handbook of Marketing Scales. Sage Publications. Newbury Park.

Beaudoin, P., Moore, M.A. \& Goldsmith, R.E. (2000). Fashion leaders' and followers' attitudes toward buying domestic and imported apparel. Clothing and Textiles Research Journal, 18, 56-64.

Blake, B.F., Valdiserri, C.M., Neuendorf, K.A. \& Valdiserri, J.N. (2007). The online shopping profile in the cross-national context: The roles of innovativeness and perceived innovation newness. Journal of International Consumer Marketing, 19, 21-51. 
Bigné-Alcañiz, E., Ruiz-Mafé, C., Aldás-Manzano, J. \& Sanz-Blas, S. (2008). Influence of online shopping information dependency and innovativeness on internet shopping adoption. Online Information Review, 32, 648-667.

Brislin, R.W. (1986). The wording and translation of research instruments, in Lonner, W.J. and Berry, J.W. (eds), Field Methods in Cross-cultural Research: Cross-cultural Research Methodology Series. Thousand Oaks, CA: Sage, 8, 137-164.

Chakrabarti, S. \& Baisya, R.K. (2009). The influences of consumer innovativeness and consumer evaluation attributes in the purchase of fashionable ethnic wear in India. International Journal of Consumer Studies, 33, 706-714.

Chao, A. \& Schor, J.B. (1998). Empirical tests of status consumption: Evidence from women's cosmetics. Journal of Economic Psychology, 19, 107-131.

Chao, C.-W., Reid, M. \& Mavondo, F.T. (2012). Consumer innovativeness influence on really new product adoption. Australasian Marketing Journal, 20, 211-217.

Citrin, A.V., Sprott, D.E., Silverman, S.N. \& Stem, D.E. Jr. (2000). Adoption of internet shopping: The role of consumer innovativeness. Industrial Management and Data Systems, 100, 294-300

Cotton Incorporated (2016). Global lifestyle monitor: China. Cotton Incorporated. Retrieved from http://www.cottoninc.com/corporate/Market-Data/SupplyChainInsights/Global-LifestyleMonitor-China-04-2016/Global-Lifestyle-Monitor-China-04-2016.pdf

Cotton Incorporated (2016). Global lifestyle monitor: India. Cotton Incorporated. Retrieved from http://www.cottoninc.com/corporate/Market-Data/SupplyChainInsights/Global-LifestyleMonitor-India-04-2016/

Debnam, N. \& Svinos, G. (2007). Luxury brands in China. KPMG. Retrieved from http://www.kpmg.com.cn/en/virtual_library/Consumer_markets/CM_Luxury_brand.pdf

Deloitte (2013). India matters: Winning in growth markets. Deloitte. Retrieved from https://www2.deloitte.com/content/dam/Deloitte/uk/Documents/about-deloitte/deloitte-ukabout-india-matters.pdf (accessed on September 27, 2017)

Deloitte (2017). China e-retail market report 2016. Deloitte. 1-42. Retrieved from https://www2.deloitte.com/content/dam/Deloitte/cn/Documents/cip/deloitte-cn-cip-chinaonline-retail-market-report-en-170123.pdf

Dunn, N. (1996). Cross-cultural comparison of consumer's perceptions of apparel quality. Unpublished Masters Thesis. Auburn University, Alabama.

ENS Economic Bureau (2017). Despite demonetisation, India's GDP growth stays 7 per cent: Govt data. The Indian Express, March 1. Retrieved from http://indianexpress.com/article/ business/economy/india-gdp-growth-rate-demonetisation-7-per-cent-cso-4548502/

Forsythe, S., Kim, J.O., \& Peter, T. (1999). Product cue usage in two Asian markets: A crosscultural comparison. Asian Pacific Journal of Management, 16, 275-292.

Gitimu, P.N., Work, J. \& Robinson, J.R. (2013). Garment quality evaluation: Influence of fashion leadership, fashion involvement, and gender. International Journal of Fashion Design, Technology and Education, 6, 173-180.

Goldsmith, R.E. (1990-1991). The validity of scale to measure global innovativeness. Journal of Applied Business Research, 7, 89-97.

Goldsmith, R.E., d'Hauteville, F. \& Flynn, L.R. (1998). Theory and measurement of consumer innovativeness: A transnational evaluation. European Journal of Marketing, 32, 340-353.

Goldsmith, R.E. \& Flynn, L.R. (1992). Identifying innovators in consumer product markets. European Journal of Marketing, 26, 42-55. 
Goldsmith, R.E. \& Flynn, L.R. (1995). The domain specific innovativeness scale: Theoretical and practical dimensions, in Moore, D.L. (Ed.), Association of Marketing Theory and Practice Proceedings, 4, 177-182.

Goldsmith, R.E. \& Hofacker, C.F. (1991). Measuring Consumer Innovativeness. Journal of the Academy of Marketing Science, 19, 209-21.

Goldsmith, R.E. \& Newell, S.J. (1997). Innovativeness and price sensitivity: Managerial, theoretical and methodological issues. Journal of Product and Brand Management, 6, 163-174.

Goldsmith, R. \& Stith, M. (1993). The social values of fashion innovators. Journal of Applied Business Research, 9, 10-17.

Gray, A. (2017). These are the world's fastest-growing economies in 2017. World Economic Forum, June 9th. Retrieved from https://www.weforum.org/agenda/2017/06/these-are-theworld-s-fastest-growing-economies-in-2017-2/

Handa, M. \& Gupta, N. (2009). Gender influence on the innovativeness of young urban Indian online shoppers. The Journal of Business Perspective, 13, 25-32.

Hauser, J., Tellis, G.J. \& Griffin, A. (2006). Research on innovation: A review and agenda for marketing science. Marketing Science, 25, 687-717.

Hirunyawipada, T. \& Paswan, A.K. (2006). Consumer innovativeness and perceived risk: implications for high technology production adoption. Journal of Consumer Marketing, 23, 182-198.

HKTDC (2016). China's 13th Five-Year Plan: The realities of rising consumer demand. Hong Kong Trade Development Council. HKTDC Research, June 28th. Retrieved from http://hkmb.hktdc.com/en/1X0A6J0F/hktdc-research/China\%E2\%80\%99s-13th-Five-YearPlan-The-Realities-of-Rising-Consumer-Demand

Hofstede, G. (2001). Culture's Consequences: Comparing Values, Behaviours, Institutions, and Organizations across Nations. $2^{\text {nd }}$ ed. Thousand Oaks, CA: Sage Publications.

Holstius, K. \& Paltschik, M. (1983). Brand names and perceived value. European Research, 11, 151-156.

Hynes, N. \& Lo, S. (2006). Innovativeness and consumer involvement in the Chinese market. Singapore Management Review, 28, 31-46.

IBEF (2016). Retail. India Brand Equity Foundation (IBEF). January. Retrieved from https://www.ibef.org/download/Retail-January-2016.pdf

Im, S., Bayus, B.L. \& Mason, C.H. (2003). An empirical study of innate consumer innovativeness, personal characteristics, and new product adoption behavior. Journal of the Academy of Marketing Science, 31, 61-73.

IMF (2015). World economic outlook database. International Monetary Fund, April. Retrieved from http://www.imf.org/external/pubs/ft/weo/2015/01/weodata/index.aspx

Jordaan, Y. \& Simpson, M.N. (2006). Consumer innovativeness among females in specific fashion stores in the Menlyn shopping centre. Journal of Family Ecology and Consumer Science. 34, 32-40.

Joseph, B. \& Vyas, S.J. (1984). Concurrent validity of a measure of innovative cognitive style. Journal of the Academy of Marketing Sciences, 12, 159-175.

Jin, B., Park, J.I. \& Ryu, J.S. (2010). Comparison of Chinese and Indian consumers' evaluative criteria when selecting denim jeans: A conjoint analysis. Journal of Fashion Marketing and Management, 14, 180-194.

Kang, J. \& Park-Poaps, H. (2010). Hedonic and utilitarian shopping motivations of fashion leadership. Journal of Fashion Marketing and Management, 14, 312-328. 
Kawabata, H. \& Rabolt, N.J. (1999). Comparison of clothing purchase behaviour between US and Japanese female university students. Journal Consumer Studies \& Home Economics, 23, 213-223.

Khan, M. (2016). Growth star India overtakes China as world's fastest growing major economy. The Telegraph, February 8th. Retrieved from http://www.telegraph.co.uk/finance/economics/ 12146579/India-overtakes-China-as-worlds-fastest-growing-major-economy.html

Khare, A. \& Rakesh, S. (2012). Predictors of fashion clothing involvement among Indian youth. Journal of Targeting, Measurement and Analysis for Marketing, 18, 209-220.

Klink, R.R. \& Athaide, G.A. (2010). Consumer innovativeness and the use of new versus extended brand names for new products. Journal of Product Innovation Management, 27, 23-32.

Kwang, J.N., Holland, R., Shackleton, J., Hwang, Y.-Y. \& Melewar, T.C. (2008). The effect of evaluation criteria on design attributes and brand equity in the product evaluation process. Brand Management, 16, 195-212.

Law, K.M., Zhang, Z.M. \& Leung, C.S. (2000). Clothing deprivation, clothing satisfaction, fashion leadership and Hong Kong young consumers. Journal of Fashion Marketing and Management, 4, 289-302.

Lim, H. \& Park, J.-S. (2013). The effects of national culture and cosmopolitanism on consumers' adoption of innovation: A cross-cultural comparison. Journal of International Consumer Marketing, 25, 16-28.

Lumpkin, J. \& McConkey, W. (1984). Identifying determinants of store choice of fashion shoppers. Akron Business and Economic Review, 15, 30-36.

Medh, K. (2012). Creating the hype, in G. Atwal and S. Jain (eds.), The Luxury Market in India: Maharajas to Masses, Palgrave Macmillan, NY: New York, 152-163.

Muzinich, N., Pecotich, A. \& Putrevu, S. (2003). A model of the antecedents and consequents of female fashion innovativeness. Journal of Retailing and Consumer Services, 10, 297-310.

National Bureau of Statistics (2017). NBS: Total retail sales of consumer goods up by $9 \%$ yoy in Jan-Feb 2017. National Bureau of Statistics, 14 March. Retrieved from http://www.stats.gov.cn/ tjsj/sjjd/201703/t20170314_1472618.html (in Chinese)

Nielson (2013). Asia Pacific consumers the most label-conscious in the world. The Neilsen Company, July 2. Retrieved from http://www.nielsen.com/my/en/press-room/2013/asiapacific-consumers-the-most-label-conscious-in-the-world.html

Nunnally, J.C. \& Bernstein, I.H. (1994). Psychometric Theory. $3^{\text {rd }}$ edn. McGraw-Hill, New York.

O'Cass, A. (2001). Consumer self-monitoring, materialism and involvement in fashion clothing. Australasian Marketing Journal, 19, 46-60.

Olson, J. C. \& Jacoby, J. (1972). Cue utilization in the quality perception process, in Advances in Consumer Research (pp. 167-179). Proceedings of the Third Annual Meeting, Association for Consumer Research.

Phau, I. \& Lo, C.-C. (2004). Profiling fashion innovators: A study of self-concept, impulse buying and Internet purchase intent. Journal of Fashion Marketing and Management, 8, 399-411.

Puddick, M. \& Menon, P. (2012). Contemporary lustre, in G. Atwal and S. Jain (eds.), The Luxury Market in India: Maharajas to Masses, Palgrave Macmillan, NY: New York, 48-68.

PwC (2017). eCommerce in China - the future is already here. PricewaterhouseCoopers Limited $(P w C), 1-36$. Retrieved from https://www.pwccn.com/en/retail-and-consumer/publications/ total-retail-2017-china/total-retail-survey-2017-china-cut.pdf 
Quigley, Jr. C.J. \& Notarantonio, E.M. (2009). A cross-cultural comparison of United States and Austrian fashion consumers. Journal of Euromarketing, 18, 233-244.

Rahman, O. (2011). Understanding consumers' perceptions and behaviour: Implications for denim jeans design. Journal of Textile and Apparel, Technology and Management, 7, 1-16.

Rahman, O., Fung, B.C.M., Chen, Z. \& Gao, X. (2017). A cross-national study of apparel consumers' preferences and the role of product evaluative cues. Asia Pacific Journal of Marketing and Logistics, 29, 1-19.

Rahman, O., Fung, B.C.M., Chen, Z. \& Gao, X. (2018). A study of apparel consumer behaviour in China and Taiwan. International Journal of Fashion Design, Technology and Education, 11, 22-23.

Rahman, O. \& Kharb, D. (2018). Fashion innovativeness in India: Shopping behaviour, clothing evaluation and fashion information sources. International Journal of Fashion Design, Technology and Education, 11, 287-298.

Rahman, O., Liu, W.-S. \& Cheung, M.-H. (2012). Cosplay: Imaginative self and performing identity. Fashion Theory: The Journal of Dress, Body \& Culture, 16, 317-342.

Rahman, O., Wong, K.K.-K. \& Yu, H. (2016). The effects of mall personality and fashion orientation on shopping value and mall approach behaviour among Chinese shoppers. Journal of Retailing and Consumer Services, 28, 155-164.

Rahman, O., Yan, J. \& Liu, W.-S. (2010). Evaluative criteria of denim jeans: A cross-national study of functional and aesthetic aspects. The Design Journal, 13, 291-311.

Rahman, O., Yan, J. \& Liu, W.-S. (2009). Evaluative criteria for sleepwear: A study of privately consumed product in the People's Republic of China. International Journal of Fashion Design, Technology and Education, 2, 81-90.

Rahman, O., Zhu, X. \& Liu W.-S. (2008). A study of the pyjamas purchasing behaviour of Chinese consumers in Hangzhou, China. Journal of Fashion Marketing and Management, 12, 217-231.

Reuters (2016). China's retail sales to reach about 48 trillion yuan by 2020 - Commerce Ministry. The Reuters, Business News, November 16. Retrieved from http://www.reuters.com/article/uschina-economy-retail-sales-idUSKBN13B0KQ

Roehrich, G. (2004). Consumer innovativeness concepts and measurements. Journal of Business Research, 57, 671-677.

Roy, S., Sethuraman, R. \& Saran, R. (2016). The effect of demographic and personality characteristics on fashion shopping proneness: A study of the Indian market. International Journal of Retail \& Distribution Management, 44, 426-447.

Sandhu, A. (2015). Indian Fashion: Tradition, Innovation, Style. Bloomsburry Academic, London, UK.

Swam, J.E. \& Combs, L.J. (1976). Product performance and consumer satisfaction: A new concept. Journal of Marketing, 40, 25-33.

The Times of India (2015). Indian retail market to reach $\$ 1.3$ trillion by 2020. The Times of India, June 1. Retrieved from http://timesofindia.indiatimes.com/business/india-business/Indianretail-market-to-reach-1-3-trillion-by-2020/articleshow/47501863.cms

Truong, Y. (2013). A cross-country study of consumer innovativeness and technological service innovation. Journal of Retailing and Consumer Service, 20, 130-137.

Uray, N. \& Dedeoglu, A. (1997). Identifying fashion clothing innovators by self-report method. Journal of Euromarketing, 6, 27-46.

Venkatraman, M.P. (1991). The impact of innovativeness and innovation type and adoption. Journal of Retailing, 67, 51-67. 
Wildau, G. \& Mitchell, T. (2017). China GDP growth points to 2017 economic rebound. Financial Times, July 17th. Retrieved from https://www.ft.com/content/6e46e302-6878-11e7-85267b38dcaef614

Wong, N.Y. \& Ahuvia, A.C. (1998). Personal taste and family face: Luxury consumption in Confucian and Western societies. Psychology and Marketing, 15, 423-441.

Workman, J.E. \& Studak, C.M. (2006). Fashion consumers and fashion problem recognition style. International Journal of Consumer Studies, 30, 75-84.

Yu, C., Xiao, F., Zhang, K., Nath, R., Lin, A., Mak, E., Yep, J., Wong, K., Rho, R., Eggleton, S. $\&$ the Economist Intelligence Unit (2015). 2015-2016 outlook for the retail and consumer products sector in Asia, $P w C$. Retrieved from http://www.pwchk.com/webmedia/doc/ 635593364 676310538_rc_outlook_201516.pdf

Zhang, G.J. (2005). Youth trends in China. Young Consumers, Quarter 1, 28-33.

Zipser, D., Chen, Y. \& Gong, F. (2016). 2016 China Consumer Report: The modernization of the Chinese consumer. March. Retrieved from file://C:/Users/osmudr/ Desktop/ Here \%20comes\%20the\%20modern\%20Chinese\%20consumer.pdf 